\title{
Planning rejection leaves British nuclear waste plans in disarray
}

[LONDON] Britain's radioactive waste disposal plans were in disarray last week as Nirex, the company charged with the job of waste disposal, effectively abandoned attempts to build an underground repository at Sellafield in the northwest of England.

At a meeting of Nirex's board last week, members decided not to appeal against the British government's decision three weeks ago to refuse Nirex's application to build an experimental research laboratory near its proposed site for a waste repository at Longland's Farm, in Cumbria.

Nirex was hoping to use the laboratory to investigate the Sellafield geology. Its decision not to appeal effectively spells the end of Sellafield as a proposed repository site. The company will now have to turn elsewhere in its quest to dispose of waste from nuclear power stations.

The company also announced "adjustments to [its] programme and resources", widely understood to mean staff redundancies. Contracts for the research laboratory have already been cancelled. And one wellplaced source suggested that Nirex's rock laboratory department would almost certainly be shut down, with the loss of scientists.

A clearly disappointed Nirex chairman, Sir Richard Morris, complained in a statement that the ground rules had kept changing. What should have been a straightforward planning inquiry into a research facility turned into a full-scale investigation of the merits of disposing of nuclear waste at Sellafield.

"We cannot get the information to show whether the site is safe or not without a rock laboratory, but it now appears we cannot win approval for a rock laboratory without first showing the site is safe."

But some of Nirex's own internal ground rules are also now coming under scrutiny, particularly the methods employed by the company in its attempts to obtain and then assess the safety of Sellafield as its chosen repository site.

The aim of the laboratory was to test the geology of the rocks, in particular to determine the risk of radioactive waste finding its

\section{IMAGE UNAVAILABLE FOR COPYRIGHT REASONS}

No future: an aerial view of Nirex's test borehole at Longlands Farm near the Sellafield plant.

way back to the surface once the containers had corroded, and the waste had leaked out.

Cumbria County Council, the local authority, rejected planning permission for the laboratory, backed by environmentalist groups such as Friends of the Earth. FoE argued that surface-based investigations remained incomplete.

A leaked internal memo from John Holmes, Nirex director for science, concurred with this view, and suggested the need for more data sampling points (see Nature $385,282 ; 1997)$.

Nirex appealed against the council's refusal, and the matter was passed to Britain's environment secretary John Gummer following a 66-day public inquiry. The inspector presiding over the inquiry recommended that Gummer, too, should refuse the application.

The leaked memo is believed to have played a crucial role in this decision, as Holmes appeared to acknowledge that, unless lower values for Sellafield's rock permeability were found, "we may struggle to

make a case for the site". Gummer said in his rejection that he was "concerned about the scientific uncertainties and technical deficiencies in the proposals presented by Nirex".

The refusal is a huge blow to the company, which has already spent more than $£ 200$ million (US\$320 million) assessing the Sellafield site. Nirex was so confident that the government would allow further site investigations that it even awarded initial contracts to build the underground laboratory before Gummer's decision was announced.

The decision lays wide open the question of what to do with the estimated 300,000 cubic metres of radioactive waste that is expected to accumulate by early next century. Nirex was expecting to begin placing waste in a repository by this time. One of its shareholders, British Nuclear Fuels, is believed to hold waste disposal contracts from other countries.

FoE has always insisted on 'retrievability' being built into any disposal plans and ideally would like Nirex to consider disposal at a shallow site. But with deep disposal having become the standard method internationally of disposing of nuclear waste, a shallow repository is unlikely.

The Labour party, which is widely expected to form the next government after the 1 May election, is believed to support deep disposal. The government was poised to publish its plans for a research strategy for disposing of high-level waste, before the election was called. Some observers now speculate that a deep and retrievable repository for intermediate level waste as well as high-level waste may now be the best way forward.

In the meantime, however, Gummer's decision also raises critical questions about whether Nirex itself is equipped to continue with the responsibility of looking for a suitable site, or whether this job should fall to a new bodyless beholden to the nuclear industry.

The selection of Sellafield as the chosen site has long been claimed by critics to have been made on grounds that were suited more to the needs of the industry than of science. Notwithstanding geological issues, a Sellafield-based repository offered clear advantages over other sites as much of Britain's nuclear industry, including British Nuclear Fuels, is already based there.

John Gummer ended his statement on refusing Nirex's planning appeal by saying that he too was "concerned about the process of site selection". His predecessors are widely believed not to have opposed Sellafield as a potential repository site.

An acute lack of transparency has been a 